\title{
THREE DECADES OF MANAGEMENT ACCOUNTING IN RUSSIA: THE EVOLUTION OF UNDERSTANDING OF MANAGEMENT ACCOUNTING CONCEPT
}

\author{
Pavel LEBEDEV (iD* \\ IEDC Bled School of Management, 4260, Presernova cesta 33, Bled, Slovenia \\ *E-mail: p.lebedev@inbox.ru
}

\begin{abstract}
Purpose- the article explores how did management accounting concept evolve and develop in Russia during the post-Soviet era. This study is informed by the specific way of the development of management accounting in Russia and a lack of related studies.

Research methodology - this is a historical study based on archival methods. Evidence was obtained from sources varying from related literature to personal field notes and reflections arising from observations and experience gained in my more than 2 decades as a consultant and educator in the field of management accounting. The analysis in this study follows an interpretive approach: a narrative analysis of evidence used the model of thematic analysis to arrive at the findings.

Findings - the results of the research demonstrate that the management accounting evolution in Russia contains three distinct periods: 1990's - transactional focus, mainly related to cost; 2000's - management accounting as an internal advisory function; 2010's - management accounting on its way to financial leadership. This evolution followed the same path as in the developed markets, however, the patterns of this typology in Russia were much weaker. The driving forces of the development of management accounting were different than in the environment of developed markets. The benefits of management accounting to the overall corporate success were insignificant at each of the discussed phases.

Research limitations - research results could be influenced by contextual nature and subjectivity of interpretative analysis, possible incompleteness and subjective selection of archival data, limited resources for analysis and interpretation.

Practical implications - the research enriches our understanding of the development of management accounting in emerging economies, and it could support decisions in the transformation of financial function along with its maturity continuum. Furthermore, this research could be used as a part of the content of programs in professional and business education.
\end{abstract}

Originality/Value - there is a lack of similar studies, which makes the research a significant contribution to existing conversations in science and professional practice.

Keywords: management accounting, management control, financial leadership, strategy, emerging markets, Russia.

JEL Classification: M40, M19.

Conference topic: Contemporary Financial Management.

\section{Introduction}

It has been truly said, that "[a]ccounting has changed, is changing, and is likely to change in the future" (Napier, 2006, p. 445). Accounting has evolved, and it continues to evolve in relation to changes in the economic, social, technological, and political environments of organizations (Hopwood, 1976). Globally, accounting has come a long way to become what is considered to lie "at the heart of an organisation, at the crossroads between finance and management" and to provide "structured solutions to unstructured problems, by translating the complex into the simple and by making the simple compelling" (The Chartered Institute of Management Accountants [CIMA], 2014, p. 6). However, this "global" dimension often relates to developed economies, where management accounting has long been considered to be a part of the internal infrastructure, supporting companies in formulating and executing their strategies (Bhimani, 1996).

Although much is known about the development of management accounting in certain countries, emerging economies traditionally were beyond the scope of mainstream research. At the international level, studies on accounting in 
post-Soviet countries are especially scarce. Most of the research rarely goes beyond the local academic environment because of the inability to conduct research according to the generally accepted international academic practices and lack of working foreign languages skills among the academic community.

The lack of local research makes it challenging to see the big picture of what is really happening in the development of management accounting across countries. Accordingly, it is difficult to reconcile local developments given the tactics that have been suggested by various reports on best practices, which are produced by professional bodies, such as The Chartered Institute of Management Accountants, The Association of Chartered Certified Accountants, Institute of Management Accountants and alike.

It is suggested that the extent of discussion of the evolutionary and contingent nature of management accounting in various publications could be much broader (Hopwood, 1977) and that conducting regional studies contributes to the understanding of related processes (Shields, 1998). Russia presents a particularly interesting geographical scope for studies of the development of management accounting because it sets the tone in the post-Soviet region due to the relative power of its economy and supporting infrastructure (e.g. education, consulting industry etc.) in comparison to other countries of the former Soviet block. Thus, Russia is a prime starting point for understanding both Russian and the wider dynamics of the region.

Management accounting in Russia is still an emerging concept (Lebedev, 2014), which has come a long way from its widely held understanding somewhat equivalent to "shadow accountancy" in the 90s to "management reporting systems" or vague assumption of the process of "identification, measurement, collection, analysis, preparation, interpretation, transmission and reception of information necessary for the management of the organization to carry out its functions" (Sheremet, 2002). It follows its own specific way. On one hand, Russia is adopting western-style business practices, commercial, legal and accounting systems, as well as approaches to management and strategy, and formal management accounting controls. However, while western-based control practices are being integrated into routines of Russian firms, the application of contemporary practices continues to be limited by many firms. On the other hand, many Russian business practices run counter to internationally accepted ways of doing business. Often these business practices rely on informal relationships and act in the environment of excess, favoritism, non-transparency, and abuses of power (Chenhall, Kallunki, \& Silvola, 2011). This leads to distortion of tools and practices and their departure from what they were initially intended to serve for; often with an opportunistic and voluntaristic redefinition of many generally accepted concepts and approaches.

The article seeks to answer the research question: "How did the management accounting concept evolve and develop in Russia during the post-Soviet era?" This research focuses on the contextual change and related management challenges that cause a transformation of the management accounting agenda and tools in use. The rest of the paper is organized as follows. A review of selected literature provides a summary of findings from the relevant publications on similar agendas. This is followed by a presentation of the methodology used in this study. Results are presented as a narrative in subsections corresponding to each of the three decades under review, each is summarized by a table containing main management challenges, and key themes in management accounting for the corresponding decade. The discussion section focuses on conceptualizing of main findings and discussing limitations and directions for further research. The conclusion is presented with a table that presents the main findings of the study.

\section{Literature review}

There is a lack of published research on accounting focused on Russia because most studies on Russia are conducted. Authors of these studies often do not have sufficient foreign languages skills that would allow them to effectively read or write in English or other languages, which is a crucial prerequisite for supporting the scientific conversation. The limited published research include those published in the early 1990s (Enthoven, 1999; Morrison, Alana, \& Abrosimova, 1993) following the overall enthusiasm of that time to perform studies of countries from the excommunist block. Research also includes the studies that examine the education of accountants in Russia (McGee \& Preobragenskaya, 2008; Smirnova, Sokolov, \& Emmanuel, 1995) and the history of Russian and Soviet accounting until the 1990s (Bailey, 1992; Liberman \& Eidinov, 1995; Platonova, 2009). This research was supplemented by investigations on the implementation of the International Financial Reporting Standards in Russia (Borker, 2012; Kim, 2013; McGee \& Preobragenskaya, 2005).

Another group of studies focuses on either other domains of accounting (Antipova \& Bourmistrov, 2013; Gaddy \& Ickes, 1999; Goncharov \& Zimmermann, 2006) or cultural and behavioral influence of management accounting (Aleksandrov, Bourmistrov, \& Grossi, 2018; Keplinger, Feldbauer-Durstmüller, \& Mitter, 2012). The most noticeable international contribution to the studies of the development of management accounting in Russia was written by Falko et al. (Falko, Becker, Malikova, Baltzer, \& Häusser, 2012; Falko, 2017, 2019). These studies provide a wide perspective on the development of management accounting in Russia during the post-Soviet time. However, they follow the ontological position of the German paradigm of controlling rather than management accounting itself. 


\section{Methodology}

\subsection{Summary of the research design}

This is a historical study based on archival methods. Evidence for this research was obtained from sources varying from related literature to personal field notes reflections on observations and experiences gained in my more than 2 decades as a consultant and educator in the field of management accounting. Analysis of this study follows an intuitive style of an interpretive approach, and a thematic analysis model of narrative analysis of evidence was conducted to arrive at the findings of this study.

A summary of the research design is presented in Figure 1, which is followed by details covered further in the related subsections.

\begin{tabular}{|c|c|c|}
\hline \multicolumn{3}{|c|}{ Historical studies } \\
\hline \multicolumn{3}{|c|}{ Archival research } \\
\hline Literature-based data & Web-based data & Personal notes (field notes/reminiscences) \\
\hline \multicolumn{3}{|c|}{ Interpretative approach / Intuitive style } \\
\hline \multicolumn{3}{|c|}{ Thematic analysis model of narrative analysis } \\
\hline
\end{tabular}

Figure 1. Research design summary (source: own work)

\subsection{Adaptation of archival research approach}

Understanding the roles of accounting in organizations and societies could be done effectively through conducting historical studies (Hopwood, 1977), whereas archival methods are often employed because they are often the only realistic option given the nature of the data (Smith, 2003) and the contingent nature of management accounting (D. Otley, 2016; D. T. Otley, 1980). Broadly defined, archival research in accounting may be based on various sources, such as historical documents, texts, journal articles, corporate annual reports, and company disclosures. This method may employ a range of approaches, ranging from the fundamental analysis of accounting numbers to the content analysis of narratives and critical approaches to the development of accounting theory (Smith, 2003).

The changing nature of accounting shifts the focus of research away from detailed technical practices to discourses in which these practices are located at a particular point in time (Napier, 2006), which redefines archival research method in management accounting providing for a certain flexibility in its application. Napier (2006) argues that "[a]lthough some of the archival evidence would be regarded as secondary sources for studies of accounting techniques, they are primary sources for rationales, meanings and interpretations", which suggest an idea of appeal for the evidence base "to a different archive rather than being non-archival" in the context of more traditional approaches.

\subsection{Evidence sources for this study}

Evidence for this study was obtained from several sources. Firstly, data are literature-based, including text-books, periodic literature (magazines, journals, newspapers), official documents (e.g. legislation acts), contemporary documentation, financial and accounting scientific and applied journals.

These data are complemented by the use of a range of secondary sources, mainly a) web-based resources websites of consulting and educational organisations, companies, web-based periodicals etc. and b) personal field notes from professional meetings (conferences, business events etc.) and documentation from consulting projects conducted with my personal participation in the during the years of 1996-2019.

Finally, data include personal reflections arising from observations and experiences gained in my more than 2 decades as a consultant and educator in the field of management accounting. Some of these reflections are in form of notes and sketches, some were published in the form of articles or blog entries, and some were presented or discussed at professional events (e.g. conferences and workshops).

\subsection{Data analysis}

The analysis in this study follows the interpretive approach. Interpretive methods of research start from the position that our knowledge of reality, including the domain of human action, is a social construction by human actors (Walsham, 2006). Interpretation is an integral part of the qualitative inquiry, whereas systematic analysis of qualitative data is always project-specific, dependent on the research question, material, and choice of analytical style (Malterud, 2001). Malterud (2001) further suggests that this analysis implies and involves:

- abstraction and some degree of generalization, which assumes that components from the individual informant's history and expressions are used to gain knowledge applicable to others;

- decontextualization - taking out parts of the subject matter for a closer investigation, together with other elements across the material that tells about similar issues; 
- recontextualisation - making sure that the patterns still agree with the context from which they were collected.

Miller and Crabtree (1999) suggest 3 styles of analysis according to the degree of predetermined categories for interpretation (as cited in Malterud, 2001). These 3 styles are summarized in Table 1.

Table 1. Analysis styles of qualitative data (source: adapted from Miller and Crabtree (Miller, 1999) as cited in (Malterud, 2001))

\begin{tabular}{|l|l|}
\hline \multicolumn{1}{|c|}{ Analysis style } & \multicolumn{1}{c|}{ Style specifics } \\
\hline $\begin{array}{l}\text { Immersion / crystallization } \\
\text { (intuitive) }\end{array}$ & $\begin{array}{l}\text { The researcher organizes data by examining the text thoroughly and then crystalizing out the } \\
\text { most important aspects }\end{array}$ \\
\hline Editing (data-based) & $\begin{array}{l}\text { The researcher identifies units in the text, forming the basis for data developed categories, } \\
\text { which are used to reorganize the text so that its meaning could be clearly seen }\end{array}$ \\
\hline Template (theory-based) & $\begin{array}{l}\text { The text is organized according to pre-existing theoretical or logical categories to provide new } \\
\text { descriptions of previously known phenomena }\end{array}$ \\
\hline
\end{tabular}

Approaches to analyzing the data may include choosing a relevant theory and establishing a data-theory link around which the research will be developed or an attempt to learning from the data itself, such as applying 'coding' process under a grounded theory approach or further adjusting of analysis techniques (Walsham, 2006). Walsham (2006) writes, "I tend to use a looser approach myself, where I write impressions during the research, after each interview, for example. I generate more organized sets of themes and issues after a group of interviews or a major field visit. I then try to think about what I have learned so far from my field data".

In this research, I apply an intuitive approach, as it was considered the most relevant, given to the large volume of unstructured data and the assumption that no particular theory would effectively support the analysis at this stage. Under this assumption, narrative analysis of evidence used the model of thematic analysis to arrive at the findings. This approach as summarized by Riessman (1993):

Narrative analysis in the human sciences refers to a family of approaches to diverse kinds of texts, which have in common a storied form. As nations and governments construct preferred narratives about history, so do social movements, organizations, scientists, other professionals, ethnic/racial groups, and individuals in stories of experience. What makes such diverse texts "narrative" is sequence and consequence: events are selected, organized, connected, and evaluated as meaningful for a particular audience. Storytellers interpret the world and experience in it... (Riessman, 1993, p.1).

Thematic analysis is a model of narrative analysis that is similar to grounded theory methodology. Thematic analysis places emphasis on the content of a text, assuming that a researcher collects many stories and inductively creates conceptual groupings from the data, organizing by theme typologies of narratives, with case studies or vignettes providing an illustration, which is a typical representational strategy (Riessman, 1993).

\section{Findings}

\subsection{0-2000: "Counting the beans": a transactional era with a focus on cost}

With the collapse of the Soviet Union, the planned economy of Russia also collapsed. Accordingly, this collapse meant the destruction of economic ties between the republics of the former Soviet Union and the countries of the socialist block. This led to the collapse of trade and production. Products that were previously produced turned out to be noncompetitive, and demand dropped dramatically. The main reasons for this were the depressing financial situation of companies, as well as the emerging potential opportunity to buy goods in developed economies (in rare cases in which financial resources were available).

This new reality presented a huge challenge to the management practices that had long existed for companies. In fact, these practices turned out to be devalued and no longer relevant in the new conditions. The showcase was management accounting, whose main role in Soviet times was purely to serve the needs of the system of state pricing, directive planning of production volumes, and distribution of funds under state budgeting financing. The main focus of decision making was on controlling the production volumes and full production costs as the basis for negotiations with authorities on plans and budgets. The prices were based on full costs, and the standard level of planned profitability and the production plans were accordingly adjusted considering the costs of producing a unit in a particular region given the existed capacity. With the transition to a market economy, all this has practically disappeared. Management faced a need for decision-making and risk-taking. However, there was a lack of newly required skills, attitudes, support systems, and infrastructure. The absence of tools and structures that could deal with financial, marketing analysis, management accounting, and controlled to the fact that the managers of enterprises in the new conditions tried to solve management goals and tasks with old, tired means.

At the same time, new trade firms, banks, financial groups, production cooperatives, which tried to find their place in the new conditions were created. These companies were created and headed by entrepreneurs, who had highrisk appetites and were able to leverage the lack of external and internal business restrictions. 
The situation was such that in the early years of the economic transition there was no demand for management accounting. The "old" companies were focused on survival at any cost, the "new" companies were making money, the professional community was not yet formed, and the state was solving more global problems of transition related to the development of state institutions. Moreover, as a paradox of the situation at that time, one can note the lack of objective necessity not only in management accounting but also in many other good management practices traditionally considered as drivers of efficiency. In the conditions of the first years of the transition to market relations, the market winners were companies that relied exclusively on productivity. These companies also paid attention to efficiency diverted valuable resources, such as time, that could be devoted to making money. The uncommonly high profitability of almost any activity at that time easily absorbed the cost of managerial mistakes.

As systems and market relations adjusted to the new reality, companies were left with smaller margins to compensate for mistakes and wrong decisions. The cost of risk increased, competition intensified, and the regulation of what was chaotic just yesterday increased. The need to evaluate decisions in advance began to arise more often. It turned out that there were almost no experts in possession of necessary tools and competencies for appraisal of managerial decisions in the new conditions. The first wave of consultants and advanced youth who were educated abroad, primarily in the United States, introduced the Anglo-Saxon management accounting logic, mainly terminology and "raw" methodologies and concepts without any adaptation - mainly the retelling of textbook content for management training programs.

At the official level, there were only a few signs of management accounting. The first sign, which was almost unnoticed and hardly appreciated by companies, was the inclusion of a special section for management accounting in an earlier version of the official chart of accounts (Ministerstvo Finansov Rossiyskoy Federatsii [MFRF], 2000). It was provided that "for management accounting purposes a company may open accounts in section 30 for each cost element" and a handful of accounts (namely - 10 accounts only from 30 to 39 with some of them blank) was offered.

Main management challenges and key themes in Russian management accounting for the period of 1990-2000 are summarized in Table 2.

Table 2. Main management challenges and key themes in management accounting from 1990-2000 (source: own work)

\begin{tabular}{|l|ll|}
\hline \multicolumn{1}{|c|}{ Main management challenges } & & Key themes in management accounting \\
\hline - $\begin{array}{l}\text { Making money alone (no management tools are em- } \\
\text { ployed) - at the early years of the decade the 1990's }\end{array}$ & $\begin{array}{l}\text { Direct costing } \\
\text { Basic understanding of the profitability of products } \\
\text { and segments }\end{array}$ & $\begin{array}{l}\text { Operational analysis, break-even point calcula- } \\
\text { tion, and related topics were discussed in detail }\end{array}$ \\
- $\begin{array}{l}\text { Basic evaluation of managerial alternatives } \\
\text { - Planning of activities and resource allocation }\end{array}$ & $\begin{array}{l}\text { Budgeting and financial responsibility centers } \\
\text { - Avoiding statutory scrutiny, yet having a good internal } \\
\text { understanding of performance }\end{array}$ & $\begin{array}{l}\text { reporting (manning and budgeting managerial } \\
\text { managerial balance sheets) }\end{array}$ \\
\hline
\end{tabular}

The use of direct-costing and operational analysis has become a reasonable alternative to the old Soviet "pot" accounting method with a full cost allocation (Lebedev, 2001). Information and analytical opportunities given by the concepts of variable and fixed costs as well as contribution margins analysis have filled the information gaps during the process of decision-making (e.g. in determining the structure and volume of sales), planning of discounts, and customer relationships. This was information that was critically lacking, and thus it was enthusiastically met by both practicing managers and the educational community.

Another important page of that time in the history of management accounting development is the importance of budgeting. Understanding budgeting in Russian practice was specific. Instead of the generally accepted understanding of budgeting as a system of financial expression of a company's plans, budgeting in Russia was considered primarily as a mechanism for optimizing costs. Many seminars, presentations at practical conferences, and publications were devoted to the importance of the introduction of budgeting. The basic idea that was brought to the audience was the following: if you want to increase profits, you need to reduce costs, but in order to control costs, you need a to budget.

A typical consulting project on implementation of a budgeting system assumed that its scope was mainly detailed planning of administrative and commercial expenses. Prior to this, it was recommended to split the company into separate accounting units. As part of the budgeting paradigm, these accounting units were called financial responsibility centers. This approach was a distorted logic of the idea of responsibility centers. The idea of separating the accounting centers as objects of management accounting was supported by the assumptions that functional managers were responsible for financial performance. The practical impossibility of the implementation of such responsibility was not taken into account. It is clear that the center of financial responsibility may be a certain unit of the internal corporate structure, headed by those responsible for all or most of the cash flows. For example, if the head of the administrative department is responsible for only a small part of the cash flow (or if he is responsible for it at all) it should not be considered as a financial responsibility center. If we consider a typical organization for the time and conditions of Russia (i.e. linear-functional type, with a deep hierarchy and an authoritarian type of leadership) then it becomes clear 
that the only owner of the budget is de facto the CEO of such a company. However, the illusion of control given by such a system turned out to be very attractive at that time. The administrative and financial departments of companies that traditionally dominate in typical Russian corporate management structures have at their disposal a status instrument of influence, which, for quite understandable reasons, has been supported by consulting companies.

The popularity of cash-flow planning and budgeting was primarily due to their proximity to the budgeting domain toolkit. Cash-flow sought to address an emerging challenge of planning financial resources. However, the first versions of implemented systems of cash planning were very basic. In essence, they represented a simple version of a daily payment schedule, which was occasionally consolidated for a longer timeframe, but rarely longer than a month.

Management reporting was considered mainly as a management balance sheet, management income statement, manage cash flows statement. The words "management" or "managerial" in the titles of these reports have well-defined context-specific meanings. As noted above, the country initially did not have any reporting framework that could represent the real financial position of a company. Lack of trust in state institutions, lack of a culture of tax relations with the state, and low financial literacy led to the perception of statutory accounting and reporting as a burden that had to be borne for the sake of complying with the minimum regulatory requirements. As a result, reporting for official purposes, in most cases, did not carry any relevant information. A typical example is the presence of zero-assets official balance sheet statements for companies representing large-scale businesses. Obviously, real assets and liabilities remained outside the scope of this reporting system. At the same time, with the emergence and growth of information needs in terms of understanding the performance and the financial state of a business, the need emerged to implement appropriate tools.

To summarize, the 1990s was marked by intensive development of management accounting. The purpose of this development has started from a blank page - it was hardly understood what the main benefits were or what the expectations were. The process was characterized both by a search of ways to apply the devalued tools, approaches from the administrative economy, and attempts to adapt "trendy" knowledge, which apparently became available from the West. However, in general, management accounting in this period was not able to jump beyond a transactional focus that emphasized costing and budgeting.

\subsection{1-2010: an era of "sense-making": management accounting as an internal advisory function}

In this decade, significant positive changes took place in Russia, which was caused both by the effectiveness of the reforms and external factors, such as, the rising prices of crude oil, on which the economy of a country essentially depends. Before the economic crisis of 2007-2008, the situation in the economy seemed to be close to ideal. For example, the level of wages in Moscow in 2007 increased by almost 30\% compared to wages in 2006. Moreover, the growth of various sectors of the economy was measured in double digits (Rosbusinessconsulting [RBC], 2008).

The positive situation in the economy contributed to the quantitative and qualitative growth of companies, the development of the market of mergers and acquisitions, and companies' decisions to make IPO. Companies experienced rapid growth, and the overall positive situation made it possible to have optimistic strategies on the agenda. The corporate agenda was determined by aggressive growth, access to new markets, mergers, and acquisitions. Supporting infrastructure and the market for consulting and professional services, business-literature, long-term and short-term business education programs was booming, and there was no lack of new ideas. The problem was ineffective and efficient implementation and ability to benefit from the next upgrade of the system. Growth stimulated active development of the labor market. The dynamism of the labor market has contributed to the mobility of qualified personnel and the involvement of specialists with education and experience in rapidly-developing companies. This brought new ideas related to management tools to companies. In the dynamically developing segment of the economy, this led to a demand for higher-level management technologies met with supply from the supporting infrastructure (e.g. the labor market and consulting).

All of this contributed to the formation of a range of new informational needs. The increasing complexity of business structures and business models has led to the need to understand the financial aspects of the functioning of various business segments, which required more fine-tuning of the reporting systems and their detailing. At the same time, the number of report holders and managers whose accountability system was based on financial indicators, increased. At the same time, a continuing problem was the lack of understanding by the majority of managers of the meaning of figures and reports. Compared with the previous decade, on the one hand, the situation was better, as the boom in business education exposed managers to many educational programs - from short-term open-enrolment seminars to MBA programs and specially customized corporate training. This contributed only to familiarity with the terminology and the general context.

Infrastructure changes also took place, which influenced the development of management accounting. For example, during 1998-2000, the Tax Code of Russia was adopted (Gosudarstvennaia Duma Rossiiskoy Federatsii [GDRF], 1998, 2000), which meant that tax accounting became the official accounting subsystem. As a matter of fact, this meant a formal division of accounting into two components - tax accounting and financial accounting. It was assumed that the separation of tax accounting, which is consistent with international good practice, will resolve methodological conflicts and solve the problems of providing reliable information within the framework of financial accounting, which now will not be affected by the specifics of tax regulations. Unfortunately, these benefits have not been received. 
Statutory financial accounting was unappreciated by companies. While some focus shifted to tax accounting, since the need for compliance was always high and the cost of errors was high, the general impression was that, since taxes and tax accounting are important for the state, and managers possessed their own, managerial accounting, only minimal efforts in financial accounting were to be made, as it was intended to no one. This situation has changed to some extent, at least for large public companies. In the 2010s, the law on consolidated reporting fully entered into force, marking the effective the transition to IFRS, at least for the big companies, which fell under its action (GDRF, 2010).

Main management challenges and key themes in management accounting for the period in question are summarized in Table 3.

Table 3. Main management challenges and key themes in management accounting from 2000-2010 (source: own work)

\begin{tabular}{|l|ll|}
\hline \multicolumn{1}{|c|}{ Main management challenges } & \multicolumn{1}{c|}{ Key themes in management accounting } \\
\hline - $\begin{array}{l}\text { Need for reliable multidimensional infor- } \\
\text { mation for decision-making to support } \\
\text { growth }\end{array}$ & - $\begin{array}{l}\text { Management reporting with a focus on segment reporting, de- } \\
\text { tailed evaluation of decisions }\end{array}$ \\
- $\begin{array}{l}\text { Strategy development/investment and fi- } \\
\text { nancing strategy }\end{array}$ & $\begin{array}{l}\text { Analysis of profitability with attempts to implement ad- } \\
\text { vanced costing systems (e.g. activity-based costing) }\end{array}$ \\
- $\begin{array}{l}\text { Managerial support for scaling-up busi- } \\
\text { nesses - a need for infrastructure for dele- } \\
\text { gation of power and authority }\end{array}$ & - $\begin{array}{l}\text { Investment appraisals (often without any understanding of } \\
\text { value-based management philosophy) }\end{array}$ \\
& - $\begin{array}{l}\text { Strategic tools. The huge popularity of Balanced Scorecard } \\
\text { Responsibility accounting - with an understanding revisited } \\
\text { from the first decade }\end{array}$ \\
\hline
\end{tabular}

As a need for reliable, multidimensional information for decision-making to support growth emerged, companies turned to implement or upgrading existing management reporting systems. As was mentioned earlier, the official accounting was not able to solve the lack of high-quality financial information to support decision-making. Only a handful of selected companies could afford to prepare financial statements according to higher standards (e.g. IFRS). Usually, these were the nation-level players, which could afford to invest heavily in the development of state-of-theart managerial tools. The rest of the companies - almost all of them - had to search for more economic decisions (not only in financial terms, but also taking in terms of time, effort, and qualification). High-level reports under such systems were usually represented with a package consisting of a detailed and "true" (in relation to statutory accounting) statements of financial position, profit and loss, and cash flows. A profit and loss statement would often be presented by segments of business (e.g. business-lines, geographic, and sales channels). Normally, they would also include regular disclosures, standardized by internal regulations. However, most non-financial managers could not read these reports. There was usually a huge gap between the financial skills and knowledge of those in charge of management accounting and business leaders, who perceived the whole management accounting function as a necessary evil (compared to official accounting which was, in this case, an unnecessary evil). This led to situations in which the implementation of management accounting was initiated because it was a matter of an image of a key decision-maker. No matter how valuable it was to show the existence of management accounting to peers, the value of information itself couldn't have been extracted because of a lack of understanding of finance.

As competition grew, the need for an understanding of the real profitability of products, services, distribution channels, and segments also grew. To solve this problem, cost management issues were again raised on the agenda. In the second decade, the development of management accounting was characterized by the accumulated educational and conceptual experience of management accountants. Notable attempts were made to consider this experience and introduce more advanced tools, rather than retelling the contents of Western textbooks. In this connection, attempts have been made both to use advanced operational analysis and to introduce activity-based costing. In general, at this time, the topic of strategic cost management is more often discussed at seminars, conferences, and business events. Unfortunately, often the use of these tools is still transactional, focused mainly on calculations, rather than reflections, although there are noticeable attempts to use these tools to stimulate managerial sense-making.

During this period, companies were actively involved in the investment process. The overall positive economy, economic growth, and expectations of projected growth made financial resources available even for very ambitious projects. Nevertheless, with the development of investment and financial relations and the strengthening of the role and the influence of investors in investment institutions, the possibilities for purely opportunistic adoption and substantiation of investment decisions were reduced. At the level of management accounting, investment appraisal became a fairly common tool. Paradoxically, despite the proliferation of NPV and IRR indicators in this context, the value-based management paradigm is not accepted by business leaders, but also by many management accountants, who regard this as a Western practice, unable, on their opinion, to successfully be applied in local conditions.

Owing to the positive growth attitudes, the tools of strategic management are gaining popularity. Companies conduct strategic sessions, where they conduct a strategic analysis of the company and develop strategies for several years. The most popular tool of this time is a balanced scorecard, which also has a very specific use in Russia. Consultants sell this tool as a practically universal solution. They suggest that this tool guarantees to build a management 
system, allowing for any financial results to be achieved in a clear way with, of course, less effort from the topmanagement side. To achieve it, large-scale projects are usually offered to perform a radical reorganization of business processes and implement an advanced automation system. In general, the issues of management accounting function that IT support is beyond the scope of this study, but it should be noted that especially in the considered decade, there was a very significant trend from IT consultants to associated management accounting with automation, i.e. in essence, it was argued that automation and implementation of, for example, ERP systems is the implementation of management accounting itself. There were examples of the large-scale attempts to "implement" a balanced scorecard with cascading up to 18,000 scorecards, which resulted in lost budgets and disappointment.

This era was also a renaissance for responsibility accounting to address a need to provide for managerial support of scaling-up businesses. The tools were needed to support management and control of distributed structures and regional expansion of companies so that the revisiting and application of the concept of responsibility centers could support mechanisms for delegating strategic tasks and management control over their implementation.

The development of management accounting in 2000-2010 was characterized by a transition from a transactionbased paradigm of management accounting to the internal advisory paradigm, where the principle role of management accountant is those of an in an internal advisor, contributing to the strategic process by providing financial expertise allowing making sense of produced information to all its receivers. However, the usage of tools was mostly fragmented without a systematic approach.

\subsection{0 - present: from "sensemaking" to "sense-giving": on the way to "financial leadership"}

After a long period of economic growth, the situation in Russia underwent major changes. The economic downturn caused by the global economic crisis of 2007-2008, as well as further crisis developments of a local nature, demonstrated serious consequences that led to radical changes in the business environment. The year 2014 was marked by a geopolitical crisis that resulted from the annexation of the Crimea and Russia's attempts to increase its influence in the east of Ukraine. The response of the global community was a series of economic sanctions that worsened the situation the rouble was devalued and many structural problems in the economy were reinforced and exposed. Some factors that contributed to the rapid growth of the Russian economy in the previous decades have ceased to exist, and they are unlikely to appear at least in the medium-term. The most obvious of these factors is high oil prices. In an attempt to gain control over the situation the state's increased regulations and provided a preferential regime for state-affiliated companies, which supported the development of a "state-capitalism" environment. All of this led to a deterioration in the economic situation for most companies. The decrease in demand and profitability and the inability to attract financing and serve current liabilities became a new reality for many market participants.

Currently, Russia is in a state of prolonged recession, the exit from which will be long. During the recovery period, slower growth is expected compared with previous decades due to the differing macroeconomic conditions. In the past two decades, companies have experienced their rapid growth, launching new products, increasing production capacity, and creating a distribution network. During this period, companies became structurally more complex, while process improvements did not occur at the same pace, and leaders paid less attention to cost optimization.

Companies that didn't have the experience of functioning in the times of crisis initially largely hoped for a quick recovery and carried out mainly tactical changes. These companies now have to adjust their view of the situation and understand the "new norm" as a given, conducting more structural changes to their business model. Since, as expected, growth after a recession will be at best limited, the market dynamics change significantly. Companies are facing a need to adapt to and change their working methods in order to prepare for new business standards. In many industries, there has been an increase in expenditures on imports and overcapacity, not only because of lower demand but also because of changes in consumer behavior. This is reflected in the dynamics of competition, which forces companies to change their business models and improve their capabilities and characteristics.

The influence of negative events demonstrated the problem of inefficiency of many Russian organizations, which were unable to work out anti-crisis measures to mitigate the impact of the global slowdown. This negative impact was huge. It became clear that many previous assumptions were unrealistic. In response to the structural nature of the current crisis, more companies began to resort to optimization measures. In the long term, a further shift is expected towards an integrated restructuring of business models, as it became clear, that maintaining competitiveness requires a radical rethinking of strategy, business models, and tools for their implementation (PricewaterhouseCoopers [PWC], 2016).

Main management challenges and key themes in management accounting for the period in question are summarized in Table 4.

Dramatic changes in the political and economic situation in the country, and, consequently, in the financial condition of companies, have led to a radical rethinking of management approaches. It became clear that many of the tools that companies introduced and used earlier were used formally and decoratively. At their best, they made a very small contribution to real results, although allowing the keep the team busy. In the new reality, managers could only invest in the tools, which could somehow help to improve the situation. In the problem of a strategic dead-end, very few tools can do this.

On top came restructuring, turnarounds, exits, and business closure. The set of tools and skills was in crucial demand, as owners and managers had to learn the concept of "exit costs" as opposed to already well-known "entry- 
costs". For many, it became clear that saving at least a part of capital is better than losing everything and the faced a hard choice of what should be left and which parts of the business are to be shut down.

Table 4. Main management challenges and key themes in management accounting from 2000-2010 (source: own work)

\begin{tabular}{|c|c|}
\hline Main management challenges & Key themes in management accounting \\
\hline $\begin{array}{ll}\text { - } & \text { Financial distress } \\
\text { - } & \text { No access to external financing } \\
\text { - } & \text { debt defaults } \\
\text { - } & \text { Strategic "dead-end" - no valid ideas on } \\
& \text { what should be done next }\end{array}$ & $\begin{array}{l}\text { - } \quad \text { Restructuring, turnarounds, exits and business closure } \\
\text { - } \quad \text { Corporate strategy refinement considering the personal strat- } \\
\text { egy of the owner based on his values } \\
\text { - } \quad \text { Business model redesign } \\
\text { - } \quad \text { cost management (revisited). Strategic cost management }\end{array}$ \\
\hline
\end{tabular}

Corporate strategy refinement considering the personal strategy of the owner based on his values supported the abovementioned process. It was the period of radical rethinking and reflections on the purposes of being in business. Only answering these personal questions could lead to solid bases for determining and shaping the future of business.

Cost management programs (revisited from the 1990s and 2000s) with an emphasis on radical cost reduction are again on the pick of popularity Strategic cost management is being discussed as an option to address both negative economic conditions and disruptions from the global players.

It can be concluded, that in 2010 until the present, sense-giving has become an important priority of management accounting and a valid expectation of its stakeholders. Sense-giving could be associated with financial leadership - the emerging role of management accountant beyond the role of a business partner. I call this new role a "trusted advisor", a role which assumes the capacity of a coach, a mentor, those who takes care of information being not only understood by recipients but also accepted by them, making it consistent with their attitudes and worldview (Lebedev, 2016). It is worth noting, however, that in the severity of this situation risk management as a systematic tool didn't appear at all. One possible explanation is that it was considered to be too "soft" of a tool, without evident outcomes at a first place.

\subsection{Summary of findings}

Management accounting in Russia is still in search of its identity (Lebedev, 2014, 2018). Its evolution followed the same path as in the developed markets, however, the patterns of this typology in Russia were much weaker. The driving forces of the development of management accounting were different than in the environment of developed markets. The benefits of management accounting to the overall corporate success were insignificant at each of the discussed phases. Table 5 below provides a summary perspective on the evolution of management accounting concept in Russia during the three decades from the 1990s to present.

Table 5. Three decades of management accounting in Russia: evolution of understanding of management accounting concept (source: based on data from the authors' research)

\begin{tabular}{|c|c|c|c|}
\hline & 1990-2000 & $2001-2010$ & $2010-$ present \\
\hline Metaphor & "Counting the beans" & "Sense-making" (internal advisory) & $\begin{array}{l}\text { "Sense-giving" (finding a } \\
\text { meaning) }\end{array}$ \\
\hline Environment & Unstructured, favorable & Favorable, friendly & Unfavorable, severe \\
\hline $\begin{array}{l}\text { The main challenge theme } \\
\text { for management }\end{array}$ & Enjoying growth & Managing growth & Managing crisis \\
\hline Main focus & Transactions processing & $\begin{array}{l}\text { Management support } \\
\text { [operating scope] }\end{array}$ & $\begin{array}{l}\text { Management support } \\
\text { [strategic scope] }\end{array}$ \\
\hline Objective & Produce reports & Drive better decisions & Ensure business' viability \\
\hline Nature of tools in use & "Number-crunching" & Analytics & Forward-looking \\
\hline Examples of tools used & $\begin{array}{l}\text { Costing, budgeting, oper- } \\
\text { ational analysis }\end{array}$ & $\begin{array}{l}\text { Segment-reporting, customer prof- } \\
\text { itability analysis, investment ap- } \\
\text { praisal, strategic analysis }\end{array}$ & $\begin{array}{l}\text { Restructuring, strategic cost- } \\
\text { management, business-model } \\
\text { redesign }\end{array}$ \\
\hline Value to management & Low & Increased & Yet to be estimated \\
\hline
\end{tabular}

\section{Discussion}

This study makes a theoretical and practical contribution to the domain of management accounting. As there is a lack of studies in a similar context, this research makes a significant contribution to existing conversations in science and professional practice by going beyond traditional Anglo-Saxon scope. This research provides insight into the development of management accounting during the new Russian history. It expands my previous research of main factors that influence and shape the development of management accounting in Russia (Lebedev, 2014). 
There are three main theoretical contributions (propositions) of the study.

1. The evolution of management accounting in Russia followed the same path as in the developed markets environment - from more technical roles of management accounting to advisory function. However, the patterns of his typology are much weaker;

2. The driving forces of the development of management accounting were different than the environment of developed markets. External shocks of various nature accelerated the change in Russia, rather than a gradual adaptation by the corporate choice of best practices and ideas of research, academia and consulting practice, hence - a relatively short period of 3 decades, were patterns of various types of management accounting are visible;

3. The benefits of management accounting to the overall corporate success were insignificant at each of the discussed phases. This is due to the tone of the top - business leaders rarely considered themselves as owners of the systems, viewing them as another [un]necessary attribute of a company.

The results of the research could be applied to support decisions in the transformation of financial function along with its maturity continuum (both conducted internally by managers and/or with external support of consultants and advisors). Namely, the results could inform the process of reconciliation of current practices of a company being transformed into a proposed transformational strategy and direction. This would allow to anticipate possible risks and manage the outcomes of the project. This maturity model is yet to be developed and grounded, both theoretically and in practical terms, which is a fruitful opportunity to build on the current work. The results of the research could also be used as a part of the content of programs in professional and business education.

The research results could be influenced by contextual nature and subjectivity of interpretative analysis, possible incompleteness and subjective selection of archival data, and limited resources for analysis and interpretation. Namely, the findings of this study are based on an analysis of open sources such as text-books, official documents, contemporary documentation, accounting, financial scientific, and applied journals, and a range of secondary sources including webbased resources and personal field notes from professional meetings. The results present an interpretation of how management accounting was perceived in the relevant periods of time by respective authors of abovementioned sources (e.g. by the authors of books and articles, teachers and instructors, and speakers at various events). Unfortunately, the voices of the companies as representatives and bearers of the practice is very limited in this study, due to very low visibility in media. This is consistent with my previous research, which revealed a low role of practicing community in influencing management accounting (Lebedev, 2014).

Although the abovementioned limitations were fully considered at the design and planning stages of the study, they determine possible avenues for future research. In particular, it would be insightful to reconcile the results presented in this study with the inside view from the companies. As data for this study mainly reflects the viewpoints of external players in relation to a company (e.g. academia, consultants, and journalists), a deeper look into what actually happens in companies is needed. Future research may follow a survey methodology to learn about actual, not perceived practices of management accounting. Also, case studies could shed light not only on the application of practices but on the related challenges and presumptions. Furthermore, if the possibility of longitudinal studies exists, they would provide important findings supporting or challenging the current research.

\section{Conclusions}

The results of the research demonstrate that management accounting evolution in Russia has passed through the three distinct periods: 1990s - transactional focus, mainly on costing; 2000s - management accounting as an internal advisory function; 2010s - management accounting on its way to financial leadership.

The initial phase, which was caused by a collapse of former economic environment and a shift to a market economy, started in early 90's and had a transactional focus, in which management accounting was mainly associated with separate basic tools mainly of calculative nature and was based primarily on financial accounting data (Falko, 2017). Primitive costing and budgeting tools were deemed appropriate to assist in finding quick solutions to emerging problems in running a business in the new market-oriented environment. These attempts were heated by a flow of Westernbased materials (e.g. books and seminars) provided by the first generation of local consultants, who had been already exposed to Western practices, either through participation in educational programs or through internships, and among other means. Management accounting was perceived as something purely internal and "intimate" as opposed to the statutory accounting. The traditional understanding of the accountant as a book-keeper assumed that management accounting books were produced and kept for the benefits of emerging capitalists, who were proud to have another attribute of a market economy, but yet most were ignorant of how it could be used for the good of their business.

In the 2000s, there was a shift of management accounting towards the role of internal management advisors. The favorable economic situation, economic growth, and the positive economic expectations created the need for tools that contribute to the development of solutions to support the expansion of companies. This is evidenced by both the level and characteristics of management accounting tools used and the newly formed needs of the stakeholders, who wanted not only to receive information within the formally existing management accounting service but also to understand what this information means for their activities and to see how their activities are reflected in numbers. Of course, the 
state of management accounting in most companies is far from the best practices of internal advisers. Nevertheless, individual patterns could have been traced.

Specifics of the modern history of management accounting in Russia - beginning in the 2010's - are determined by global and local crises of various natures. Previously, most companies focused on leveraging rapid market growth, which was largely determined by supply. Demand increased at such a rapid pace across all segments that companies built new factories, introduced new products to the market, expanded and entered new regions, and competed for new customers and new markets. Over the past 20 years, Russian companies have used an organizational model designed for rapid growth, a model that has now lost its relevance. At the same time, rapid growth contributed to the complexity of the organizational structure and an increase in the scale of companies. The change in the situation has shown that the presence of the formal attributes of any management tools does not mean that these tools function effectively. This requires not only their conscious choice and implementation but also an understanding of the purpose both in the narrow sense (at the level of functional strategies) and in the global sense. In the best management accounting practices, there are patterns of transition to financial leadership - transforming the role of internal consultants into trusted advisors, who support the managerial process by founding the financial and strategic discussion on values and meaning.

Finally, it should be noted that the findings are an interpretation of what was happening mainly in the best practices as described in many sources analyzed. They represent a wide array of publications and field notes. The essential feature of these sources is that they are themselves secondary sources, which implies that they are interpretations of companies' practices. In this respect, they are biased in terms of selection in that there is a tendency to write about successful companies, yet their share in the overall population is usually fractional. Further research should focus on the immediate voice of the companies themselves. It would be interesting to see primary evidence based on research methodology to understand the bigger picture and case studies to scrutinize the experiences of particular companies.

\section{References}

Aleksandrov, E., Bourmistrov, A., \& Grossi, G. (2018). Participatory budgeting as a form of dialogic accounting in Russia: actors' institutional work and reflexivity trap. Accounting, Auditing \& Accountability Journal, 31(4), 1098-1123. https://doi.org/10.1108/AAAJ-02-2016-2435

Antipova, T., \& Bourmistrov, A. (2013). Is Russian public sector accounting in the process of modernization? An analysis of accounting reforms in Russia. Financial Accountability \& Management, 29(4), 442-478. https://doi.org/10.1111/faam.12021

Bailey, D. (1992). The attempt to establish the Russian accounting profession 1875--1931. Accounting, Business \& Financial History, 2(1), 1-24. https://doi.org/10.1080/09585209200000024

Bhimani, A. (Ed.). (1996). Management Accounting: European Perspectives. Oxford: Oxford University Press.

Borker, D. R. (2012). Stepped-up progress on IFRS in Russia: History in the making. The International Business \& Economics Research Journal (Online), 11(2), 255. https://doi.org/10.19030/iber.v11i2.6795

Chenhall, R. H., Kallunki, J.-P., \& Silvola, H. (2011). Exploring the relationships between strategy, innovation, and management control systems: The roles of social networking, organic innovative culture, and formal controls. Journal of Management Accounting Research, 23(1), 99-128. https://doi.org/10.2308/jmar-10069

Enthoven, A. J. H. (1999). Russia's accounting moves west. Strategic Finance, 81(1), 32-38.

Falko, S., Becker, W., Malikova, S., Baltzer, B., \& Häusser, L. (2012). Controlling-lehre in Russland-status quo und vergleich mit Deutschland. Controlling, 24(6), 337-343. https://doi.org/10.15358/0935-0381-2012-6-337

Falko, S. G. (2017). Management accountants in Russia. The Role of the Management Accountant: Local Variations and Global Influences. https://doi.org/10.4324/9781315673738-10

Falko, S. G. (2019). Mission, aktueller stand und entwicklungsperspektiven des controllings in Russland. In Wertschöpfung in der Betriebswirtschaftslehre (pp. 329-339). Springer. https://doi.org/10.1007/978-3-658-18573-2_14

Gaddy, C., \& Ickes, B. W. (1999). An accounting model of the virtual economy in Russia. Post-Soviet Geography and Economics, 40(2), 79-97. https://doi.org/10.1080/10889388.1999.10641101

Goncharov, I., \& Zimmermann, J. (2006). Earnings management when incentives compete: The role of tax accounting in Russia. Journal of International Accounting Research, 5(1), 41-65. https://doi.org/10.2308/jiar.2006.5.1.41

Gosudarstvennaia Duma Rossiiskoy Federatsii. Nalogovyi kodeks Rossiyskoi Federatsii. Chast' pervaia (1998). Moscow: Gosudarstvennaya Duma Rossiyskoy Federatsii.

Gosudarstvennaia Duma Rossiiskoy Federatsii. Nalogovyi kodeks Rossiyskoi Federatsii. Chast' vtoraia (2000). Gosudarstvennaia Duma Rossiiskoy Federatsii.

Gosudarstvennaia Duma Rossiiskoy Federatsii. Federal'nyi zakon “O konsolidirovannoi finansovoi otchetnosti” (2010). Moscow: Gosudarstvennaia Duma Rossiiskoy Federatsii.

Hopwood, A. G. (1976). Editorial: The path ahead. Accounting, Organizations and Society, (1), 1-4. https://doi.org/10.1016/0361-3682(76)90002-7

Hopwood, A. G. (1977). Editorial. Accounting, Organizations and Society, (2), 277-278. https://doi.org/10.1016/0361-3682(77)90017-4

Keplinger, K., Feldbauer-Durstmüller, B., \& Mitter, C. (2012). Management accounting practices in a multicultural environment: Evidence from Austria, Russia and the US. International Journal of Strategic Management, 12(1), 37-49. https://doi.org/10.2139/ssrn.2009635 
Kim, O. (2013). Russian accounting system: Value relevance of reported information and the IFRS adoption perspective. The International Journal of Accounting, 48(4), 525-547. https://doi.org/10.1016/j.intacc.2013.10.007

Lebedev, P. (2001). Kontrolling: teoriya, metodika, praktika. Minsk: UP «IVTS Minfina».

Lebedev, P. (2014). Evolution of management accounting concept in Russia: in a search of identity. Procedia-Social and Behavioral Sciences, 156, 580-584. https://doi.org/10.1016/j.sbspro.2014.11.244

Lebedev, P. (2016). "Accounting" for leadership in management accounting and control: Exploration of current conversations. In 21st International Scientific Conference "Smart and Efficient Economy: Preparation for the Future Innovative Economy." Brno.

Lebedev, P. (2018). Management accounting in Russian mid-sized companies: results of an extended survey-based study. In Globalization and its socio-economic consequences (Vol. 3, pp. 1196-1203).

Liberman, L. V, \& Eidinov, A. M. (1995). The development of accounting in tsarist Russia and the USSR. European Accounting Review, 4(4), 777-807. https://doi.org/10.1080/09638189500000050

Malterud, K. (2001). Qualitative research: standards, challenges, and guidelines. The Lancet, 358(9280), 483-488. https://doi.org/10.1016/S0140-6736(01)05627-6

McGee, R. W., \& Preobragenskaya, G. G. (2005). Problems of implementing international financial reporting standards in a transition economy: A case study of Russia. Accounting and Financial System Reform in a Transition Economy: A Case Study of Russia, 7-40. https://doi.org/10.1007/978-0-387-25708-2_21

McGee, R. W., \& Preobragenskaya, G. G. (2008). Accounting education in Russia and the USA: A comparative study. In Accounting Reform in Transition and Developing Economies (pp. 317-335). Springer.

Miller, W. L. (1999). Clinical research: A multimethod typology and qualitative roadmap. Doing qualitative research. Edited by: Crabtree BF, Miller WL. 1999. Thousand Oaks, Sage Publications.

Ministerstvo Finansov Rossiyskoy Federatsii. Ob utverzhdenii plana schetov bukhgalterskogo ucheta finansovo-khozyaystvennoi deyatel'nosti organizatsii i instruktsii po yego primeneneniiu (2000). Moscow: Ministerstvo Finansov Rossiyskoy Federatsii.

Morrison, Alana D. and Abrosimova, I. (1993). Accounting's evolution in Russia. Management Accounting, 71(11), 18-19. https://doi.org/10.1097/00004010-199301810-00008

Napier, C. J. (2006). Accounts of change: 30 years of historical accounting research. Accounting, Organizations and Society, 31(45), 445-507. https://doi.org/10.1016/j.aos.2005.12.004

Otley, D. (2016). The contingency theory of management accounting and control: 1980--2014. Management Accounting Research, 31, 45-62. https://doi.org/10.1016/j.mar.2016.02.001

Otley, D. T. (1980). The contingency theory of management accounting: achievement and prognosis. In Readings in accounting for management control (pp. 83-106). Springer. https://doi.org/10.1007/978-1-4899-7138-8_5

Platonova, N. V. (2009). Peter the Great's government reforms and accounting practice in Russia. Accounting History, 14(4), 437464. https://doi.org/10.1177/1032373209342476

PWC. (2016). Zatyazhnoy spad v ekonomike. Chto predprinimayut potrebiteli i biznes $v$ Rossii.

RBC. (2008). No Title. Retrieved January 15, 2018, from https://www.rbc.ru/society/28/01/2008/5703cae69a79470eaf768f02

Riessman, C. K. (1993). Narrative analysis (Vol. 30). Sage.

Sheremet, A. (2002). Upravlencheskii uchet: uchebnoie posobiie. Moscow: ID FBK-PRESS.

Shields, M. D. (1998). Management accounting practices in Europe: A perspective from the States. Management Accounting Research, 9, 501-513. https://doi.org/10.1006/mare.1998.0081

Smirnova, I. A., Sokolov, J. V, \& Emmanuel, C. R. (1995). Accounting education in Russia today. European Accounting Review, 4(4), 833-846. https://doi.org/10.1080/09638189500000053

Smith, M. (2003). Research methods in accounting. SAGE Publications. https://doi.org/10.4135/9781849209809

The Chartered Institute of Management Accountants. (2014). Global management accounting principles.

Walsham, G. (2006). Doing interpretive research. European Journal of Information Systems, 15(3), 320-330. https://doi.org/10.1057/palgrave.ejis.3000589 